TELEMATIKA, Vol. 06, No. 02, JANUARI, 2010, Pp. 59 - 66

ISSN 1829-667X

\title{
SISTEM PENDUKUNG KEPUTUSAN UNTUK PEMBORAN SUMUR MINYAK BERDASARKAN PERHITUNGAN EKONOMI
}

\author{
Herry Sofyan, Frans Richard Kodong, Anggun Setyaning Widhi \\ Universitas Pembangunan Nasional "Veteran" Yogyakarta \\ anggun widhi@yahoo.com
}

\begin{abstract}
Oil represent one of nature resource which is not new but represent the solid industry of capital, technological solid and have the high risk. This matter need system of decision supporter capable to give the economics analysis needed by taker of decision or decision maker to analyse the prospect of development economics well of oil drilling so that can be made by a decision base of whether the oil well competent developed or not. Intention of this system is to give the amenity for user in taking decision of whether an developed competent oil well or not. Hence from that felt important to be designed and develop by system of decision supporter for the drilling of oilwell pursuant to economic calculation.

In this system economics parameter used in the form of Net Present Value (NPV), Rate Of Return ( ROR), Profit To Investment Ratio ( PEAR), and Pay Out Time ( POT). Methodologies used in develop this system method of Water Fall and this system will be develop to use the software Delphi 7.0.

This system will give the output in the form of decision base whether competent oil well drilling project to be developed or not pursuant to its economics calculation.
\end{abstract}

Keyword : Net Present Value (NPV), Rate Of Return (ROR), Profit to Investment Ratio (PIR), Pay Out Time (POT).

Minyak merupakan salah satu sumber daya alam yang tidak terbaharukan namun merupakan industri yang padat modal, padat teknologi dan mempunyai resiko yang tinggi. Hal ini memerlukan suatu sistem pendukung keputusan yang mampu memberikan analisa ekonomi yang diperlukan oleh pengambil keputusan atau decision maker untuk menganalisa prospek keekonomian pengembangan suatu sumur pemboran minyak sehingga dapat dijadikan dasar keputusan apakah sumur minyak tersebut layak dikembangkan atau tidak. Tujuan dari sistem ini adalah untuk memberikan kemudahan bagi user dalam mengambil keputusan apakah suatu sumur minyak layak dikembangkan atau tidak. Maka dari itu dirasa penting untuk dirancang dan dibangun sistem pendukung keputusan untuk pemboran sumur minyak berdasarkan perhitungan ekonomi.

Dalam sistem ini parameter keekonomian yang digunakan berupa Net Present Value (NPV), Rate Of Return (ROR), Profit to Investment Ratio (PIR), dan Pay Out Time (POT). Metodologi yang digunakan dalam membangun sistem ini adalah metode Water Fall (air terjun) dan sistem ini akan dibangun menggunakan perangkat lunak Delphi 7.0.

Sistem ini akan memberikan output berupa dasar keputusan apakah suatu proyek pemboran sumur minyak layak untuk dikembangkan atau tidak berdasarkan perhitungan ekonominya.

Kata Kunci: Net Present Value (NPV), Rate Of Return (ROR), Profit to Investment Ratio (PIR), Pay Out Time (POT).

\section{Pendahuluan}

Minyak merupakan salah satu sumber daya alam yang tidak terbaharukan namun merupakan industri yang padat modal, padat teknologi dan mempunyai resiko yang tinggi. Hal ini memerlukan suatu sistem pendukung keputusan yang mampu memberikan analisa ekonomi yang diperlukan oleh pengambil keputusan atau decision maker untuk menganalisa prospek keekonomian pengembangan suatu sumur pemboran minyak sehingga dapat dijadikan dasar keputusan apakah sumur minyak tersebut layak dikembangkan atau tidak. Maka dari itu dirasa penting untuk dirancang dan dibangun sistem pendukung keputusan untuk pemboran sumur minyak berdasarkan perhitungan ekonomi. 
Berdasarkan latar belakang masalah diatas, maka dapat dirumuskan bagaimana membangun sistem pendukung keputusan yang dapat membantu pengambil keputusan dalam mengkaji lebih lanjut apakah suatu proyek pemboran sumur minyak layak untuk dikembangkan atau tidak berdasarkan perhitungan ekonominya.

Tujuan penelitian ini adalah membangun suatu sistem pendukung keputusan untuk menentukan apakah suatu proyek pemboran sumur minyak layak untuk dikembangkan atau tidak yang didasarkan pada perhitungan ekonominya.

\section{Tinjauan Pustaka}

Sistem Pendukung Keputusan (Decision Support System)

Konsep Sistem Pendukung Keputusan / Decision Support System pertama kali diungkapkan pada awal tahun 1970-an oleh Michael S. Scott Morton dengan istilah Management Decision System. Definisi dari Sistem Pendukung Keputusan adalah suatu sistem berbasis komputer yang ditujukan untuk membantu pengambilan keputusan dalam memanfaatkan data dan model tertentu untuk memecahkan berbagai persoalan yang tidak terstruktur (Daihani, 2001).

Sistem Pendukung Keputusan mengacu pada suatu sistem yang memanfaatkan dukungan komputer dalam proses pengambilan keputusan. Hal ini dikemukakan oleh beberapa ahli, diantaranya Little Man dan Watson memberi definisi bahwa Sistem Pendukung Keputusan merupakan suatu sistem yang interaktif, yang membantu pengambil keputusan melalui penggunaan data dan model-model keputusan untuk memecahkan masalah-masalah yang sifatnya semi terstruktur dan tidak terstruktur.

\section{Perhitungan Ekonomi}

Untuk mengetahui bahwa suatu lapangan memberikan nilai ekonomis atau tidak, maka perlu dilakukan analisa keekonomian. Dalam penelitian ini analisa keekonomian dilakukan dengan menggunakan standart penilaian keekonomian dalam industri perminyakan dengan menghitung parameter-parameter ( Widjajono, 2002):

\subsubsection{Net Present Value (NPV)}

Net Present Value (NPV) menunjukkan jumlah pendapatan dikurangi total biaya selama proyek. NPV merupakan nilai keuntungan bersih dari suatu proyek yang diukur pada saat sekarang. Suatu proyek dikatakan menguntungkan jika nilai NPV yang diperoleh adalah positif, jika nilai NPV suatu proyek adalah negatif maka dapat dikatakan proyek tersebut mengalami kerugian. Sedangkan jika NPV besarnya nol maka besarnya pengeluaran untuk menyelenggarakan proyek sama dengan besarnya penerimaan.

\subsubsection{Payback Period (PBP) atau Pay Out Time (POT)}

Payback Period adalah suatu periode yang diperlukan untuk dapat menutup kembali pengeluaran investasi dengan menggunakan "proceeds" atau aliran kas netto (netto cash flows). Dengan demikian payback period dari suatu investasi menggambarkan panjangnya waktu yang diperlukan agar dana yang tertanam pada suatu investasi dapat diperoleh kembali seluruhnya.

\subsubsection{Profit to Investment Ratio (PIR)}

Profit to Investment Ratio (PIR) disebut juga Return of Investment (ROI) merupakan perbandingan dari keuntungan bersih yang tidak dipotong terhadap besarnya investasi yang ditanam. PIR merupakan bilangan yang tidak berdimensi yang menghubungkan jumlah yang dihasilkan dari proyek investasi tiap dollar yang ditanam.

\subsubsection{Discounted Profit to Investment Ratio (DPIR)}

Discounted Profit to Investment Ratio (DPIR) merupakan perbandingan dari keuntungan bersih yang tidak dipotong terhadap besarnya investasi yang ditanam.

\subsubsection{Rate Of Return (ROR)}

Rate of Return (ROR) adalah bunga yang menyebabkan harga semua cash inflow sama besarnya dengan cash outflow bila cashflow ini di-discount atau digandakan. Dengan kata lain Rate Of Return adalah bunga yang membuat harga sekarang dari semua penerimaan sama dengan harga sekarang dari penanaman modal. 


\section{Borland Delphi 7.0}

Delphi merupakan perangkat pengembang aplikasi yang sangat terkenal dilingkungan Windows. Delphi menyediakan dua cara untuk membuat program database. Cara pertama adalah cara konvensional yaitu menggunakan komponen TTable. Cara ini biasanya digunakan untuk pemrograman database stand alone, artinya bukan pada jaringan. Cara kedua adalah dengan SQL (Structured Query Language) dan biasanya digunakan pada pemrograman klien/server (client/server programming) (Pranata, 1998).

\section{SQL}

SQL (Structure Query Language) secara garis besar dibagi menjadi dua bagian yaitu SQL Server dan SQL Client. SQL Server diperkenalkan pada tahun 1990 untuk platform Microsoft OS/2 dalam kerjasamanya dengan Sybase. Aplikasi ini setara dengan Oracle Server, MySQL Server, DB2 dari IBM, Informix, atau Interbase. SQL Server memakai sebuah tipe database yang dinamakan database relational. Database relational adalah database yang mengorganisasikan data dalam bentuk tabel. Tabel dibentuk dengan mengelompokkan data yang mempunyai subjek yang sama. Tabel berisi baris-baris dan kolom-kolom informasi (Inge,2003).

\section{Hasil dan Pembahasan \\ Analisis Kebutuhan}

Berdasarkan deskripsi masalah diatas, nampak adanya kebutuhan akan sistem pendukung keputusan yang dapat membantu menentukan layak atau tidaknya suatu proyek pemboran sumur minyak untuk dikembangkan. Entitas yang terlibat dalam sistem ini dapat terlihat pada tabel 3.1 dibawah ini.

Tabel 3.1. Kebutuhan Pengguna Sistem

\begin{tabular}{|c|l|l|}
\hline No & \multicolumn{1}{|c|}{ Pihak Pengguna } & \multicolumn{1}{c|}{ Jenis Kebutuhan } \\
\hline 1. & Petugas Administrasi & 1. $\begin{array}{l}\text { Fasilitas untuk menyimpan dan } \\
\text { merawat data. }\end{array}$ \\
& & 2. $\begin{array}{l}\text { Fasilitas untuk membuat laporan nilai } \\
\text { keekonomian proyek. }\end{array}$ \\
& 3. $\begin{array}{l}\text { Fasilitas untuk menentukan nilai } \\
\text { keekonomian proyek berdasarkan } \\
\text { perhitungan ekonomi. }\end{array}$ \\
\hline 2. & Top Managament & 1.Laporan nilai keekonomian proyek. \\
\hline
\end{tabular}

Diagram konteks Sistem Pendukung Keputusan untuk pemboran sumur minyak berdasarkan perhitungan ekonomi ditunjukkan pada gambar 3.1 dibawah ini:

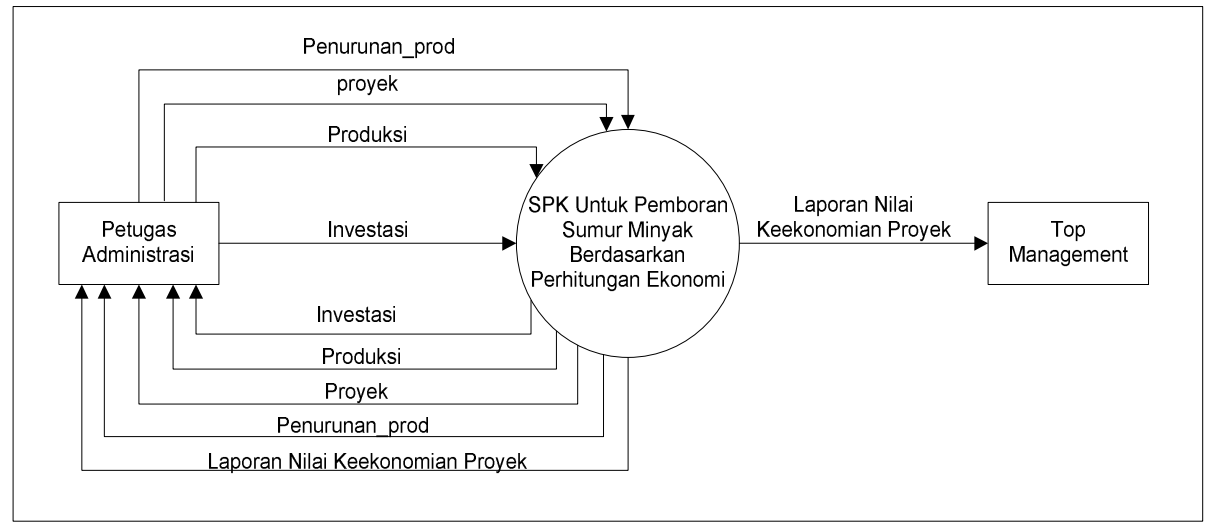

Gambar 3.1. Diagram Konteks SPK Untuk Pemboran Sumur Minyak Berdasarkan Perhitungan Ekonomi 


\section{Rancangan Proses}

Rancangan sistem ini secara keseluruhan dibagi menjadi dua proses seperti terlihat pada tabel 3.2 dibawah ini.

Tabel 3.2 Proses Utama Perhitungan Nilai Keekonomian

\begin{tabular}{|c|l|l|}
\hline No & \multicolumn{1}{|c|}{ Nama Proses } & \multicolumn{1}{|c|}{ Keterangan } \\
\hline 1. & Pengolahan Data Proyek & $\begin{array}{l}\text { Pengolahan data proyek meliputi } \\
\text { penambahan data, perubahan data, } \\
\text { penghapusan data. }\end{array}$ \\
\hline 2. & $\begin{array}{l}\text { Perhitungan Nilai Keekonomian } \\
\text { Proyek }\end{array}$ & $\begin{array}{l}\text { Proses untuk menghitung nilai } \\
\text { keekonomian proyek. }\end{array}$ \\
\hline
\end{tabular}

Data masukan terdiri dari data proyek, data produksi, dan data investasi. Masukan dari data proyek meliputi project_ID, project name, project life, crude oil price, discount rate factor, contractor profit split, government profit split, income tax, dan operating cost bbl. Dari ketiga masukan tersebut nantinya akan diproses sehingga menghasilkan data keluaran. Data keluaran yang dihasilkan berupa perhitungan nilai keekonomian suatu proyek.

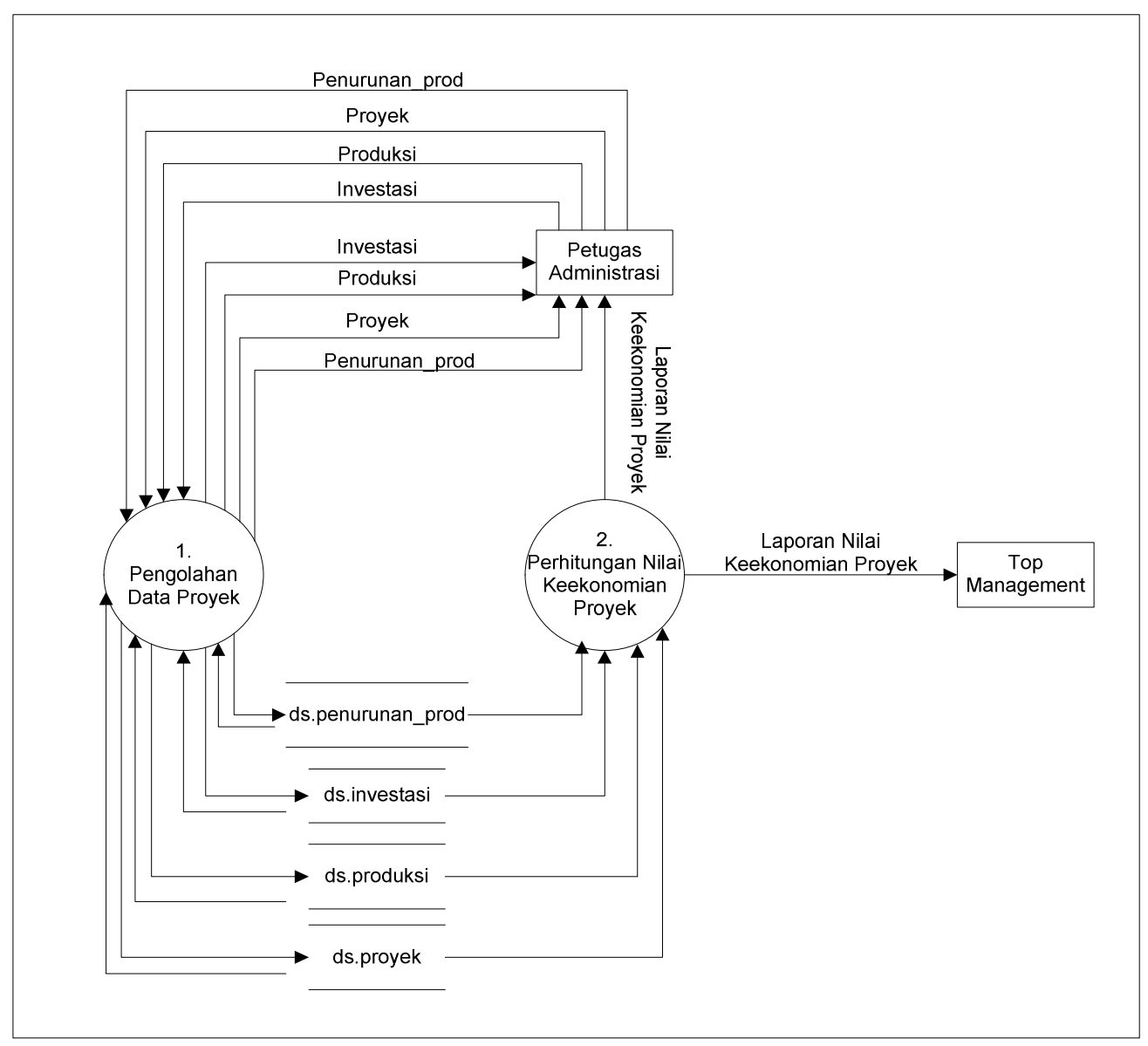

Gambar 3.2. Data Flow Diagram Level 1 


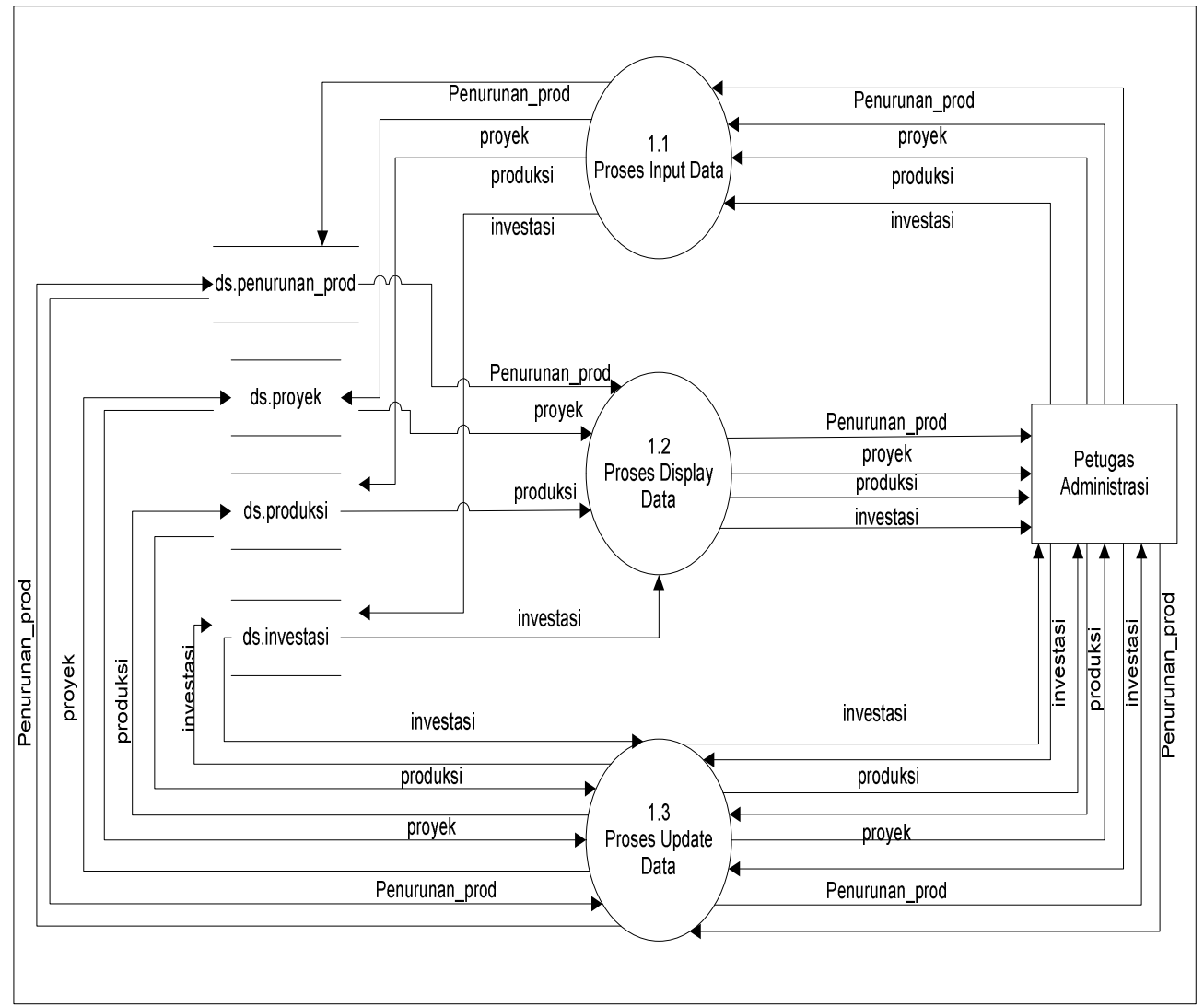

Gambar 3.3. Data Flow Diagram Level 2 untuk Pengolahan Data Proyek

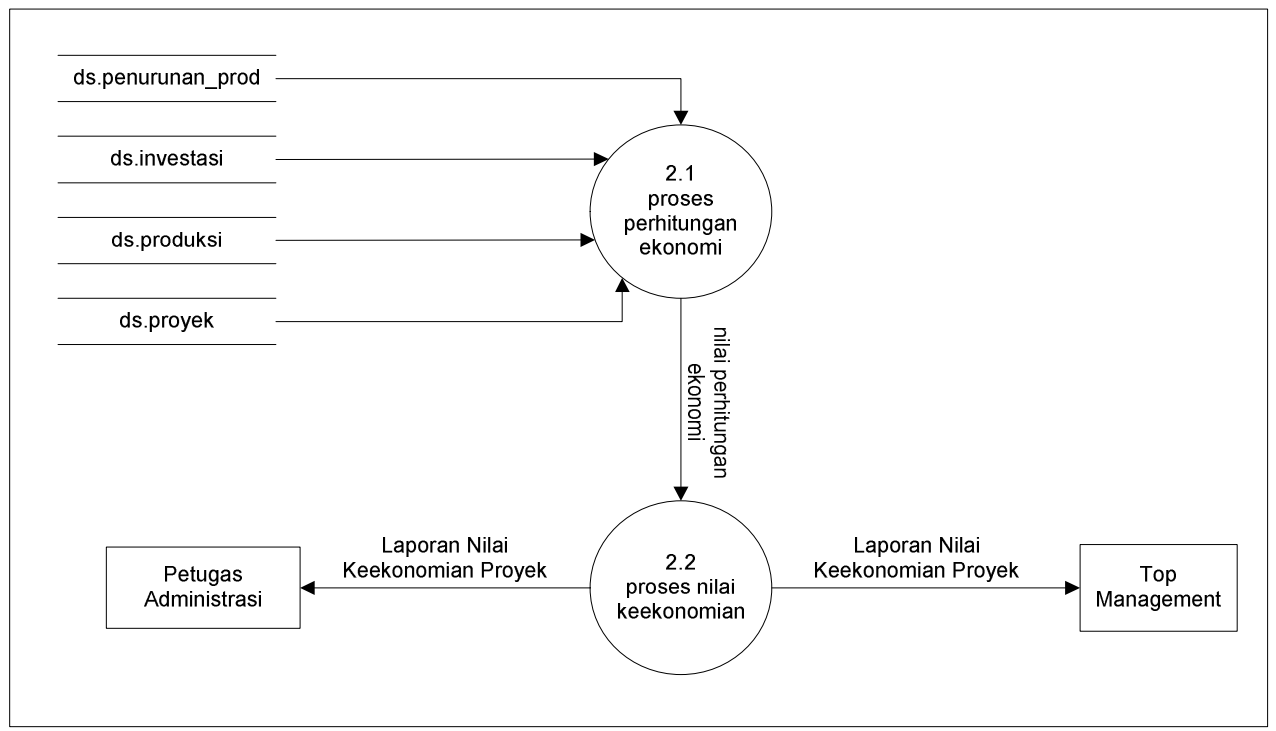

Gambar 3.4. Data Flow Diagram Level 2 untuk Proses Perhitungan Ekonomi

\section{Diagram E-R}

Entitas yang diperlukan akan digambarkan dengan menggunakan Diagram EntityRelationship (Diagram E-R). Dengan model relational, entitas-entitas ini akan menjadi tabel. Model Diagram E-R sistem pendukung keputusan untuk pemboran sumur minyak berdasarkan perhitungan ekonomi akan ditunjukkan pada gambar 3.23, sedangkan atribut / field yang terkandung dalam tabel tersebut ditunjukkan pada rancangan database. 


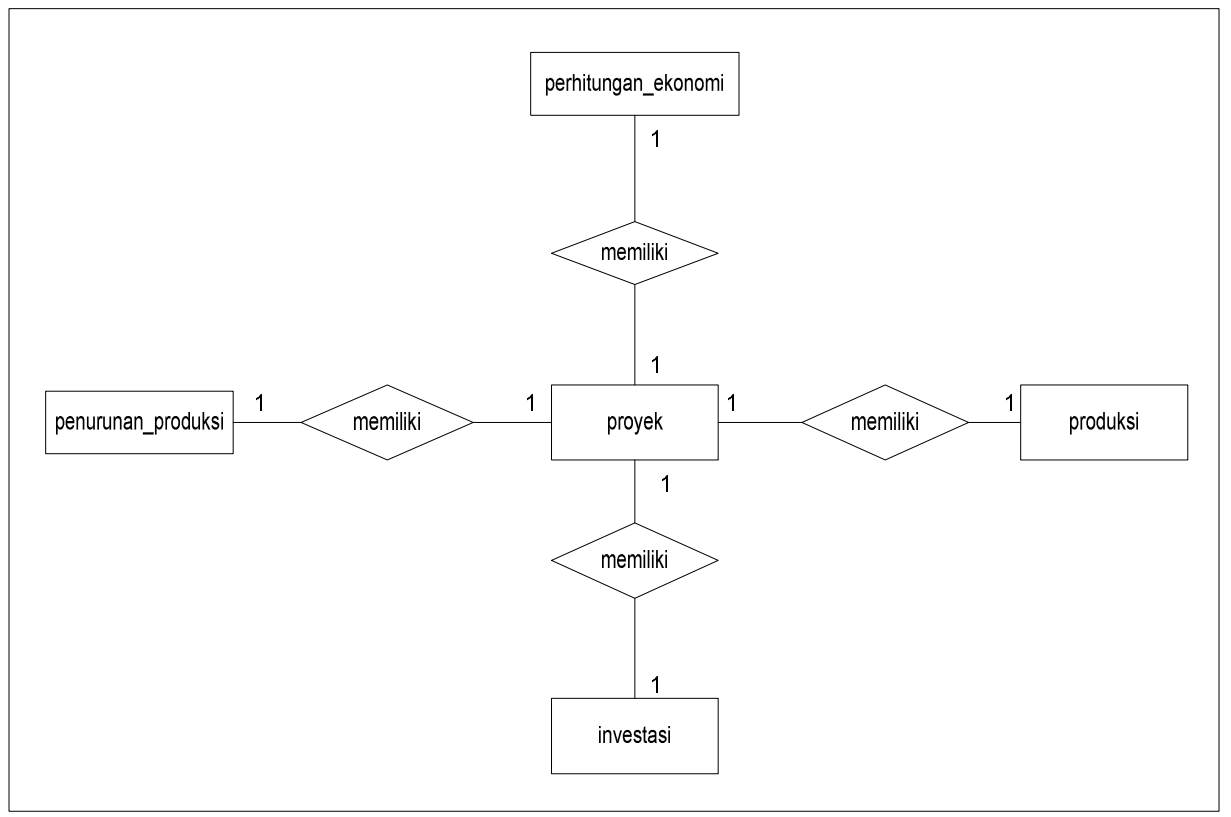

\section{Gambar 3.5 ERD Perhitungan Nilai Keekonomian}

Kamus data untuk diagram E-R pada gambar 3.23 adalah sebagai berikut :

1) Proyek = \{project ID, project_name, project_life, crude_oil, discount_rate, cont_profit, gov profit, income tax, op costbbl\}

2) Produksi $=\{$ project_ID, tahun prod, produksi $\}$

3) Penurunan_produksi $=\{$ project_ID, di1, di2, di3, di4 $\}$

4) Investasi $=\{$ project_ID, tahun invest, invest_cap, invest_noncap $\}$

5) Perhitungan_ekonomi $=\{$ project_ID, di, tahun, production_yearly, capital_invest, noncap_invest, gross_revenue, operating_cost, total_expenditure, depreciation, totcost_recovery, equity_split, contractor_share, government_share, tax, net_govshare, cash_flow, discount_factor,disc_netcashflow, cum_netcashflow, totgov_income, totdisc_netcashflow, cum_income\}.

\section{Tampilan Antarmuka}

Untuk tampilan antarmuka akan ditampilkan pada gambar berikut:

a. Antarmuka Menu Utama

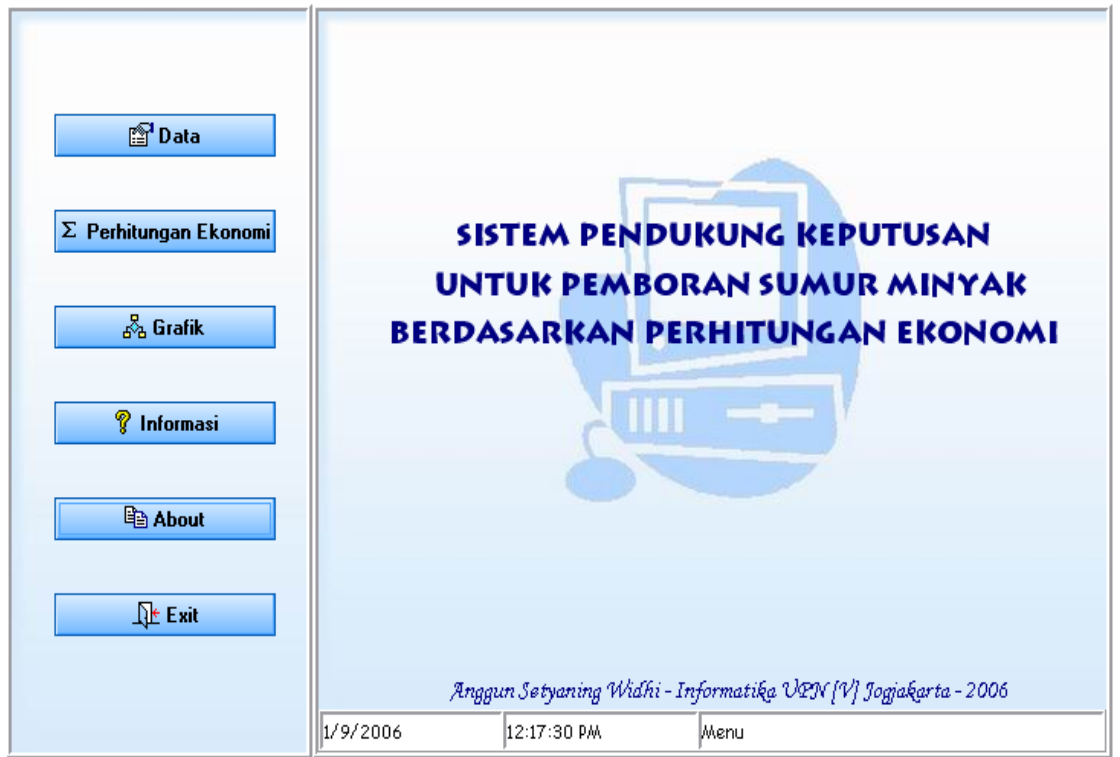

Gambar 3.6. Antarmuka Menu Utama 
b. Antarmuka Data Proyek

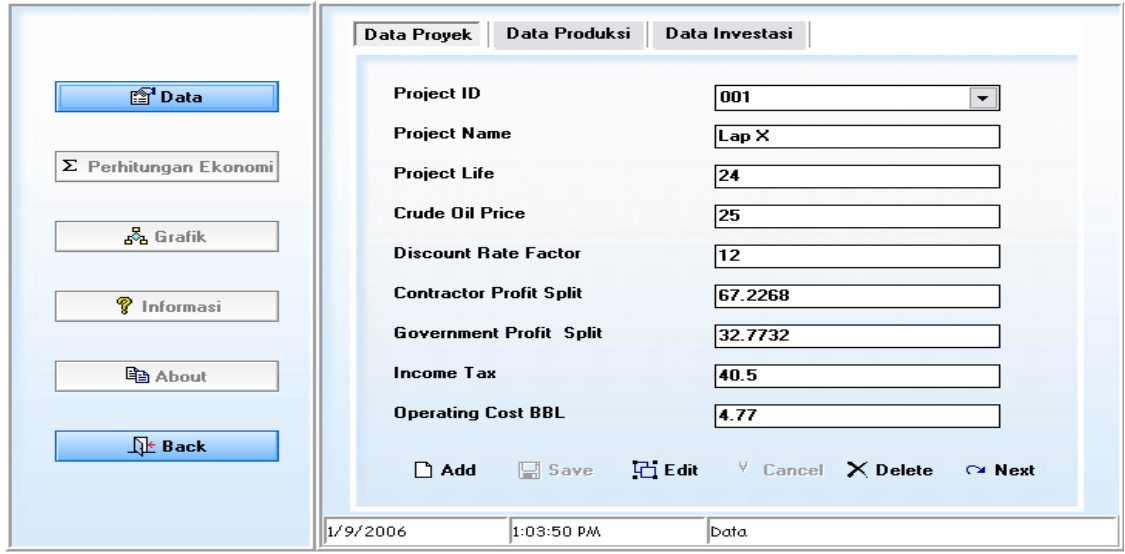

\section{Gambar 3.7. Antarmuka Data Proyek}

\section{c. Antarmuka Perhitungan Ekonomi}

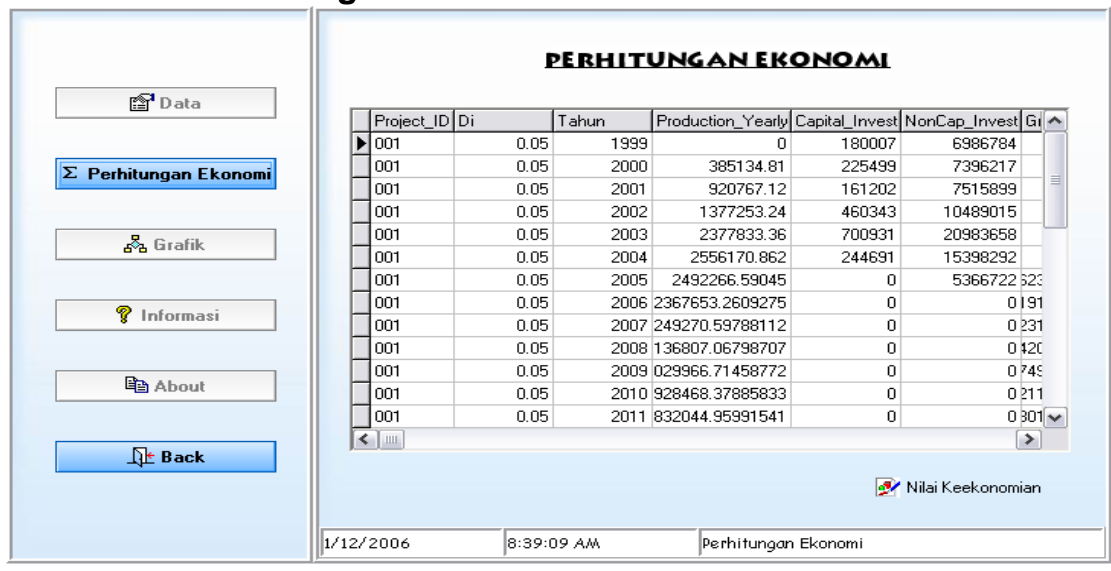

Gambar 3.8. Antarmuka Perhitungan Ekonomi

d. Antarmuka Nilai Keekonomian

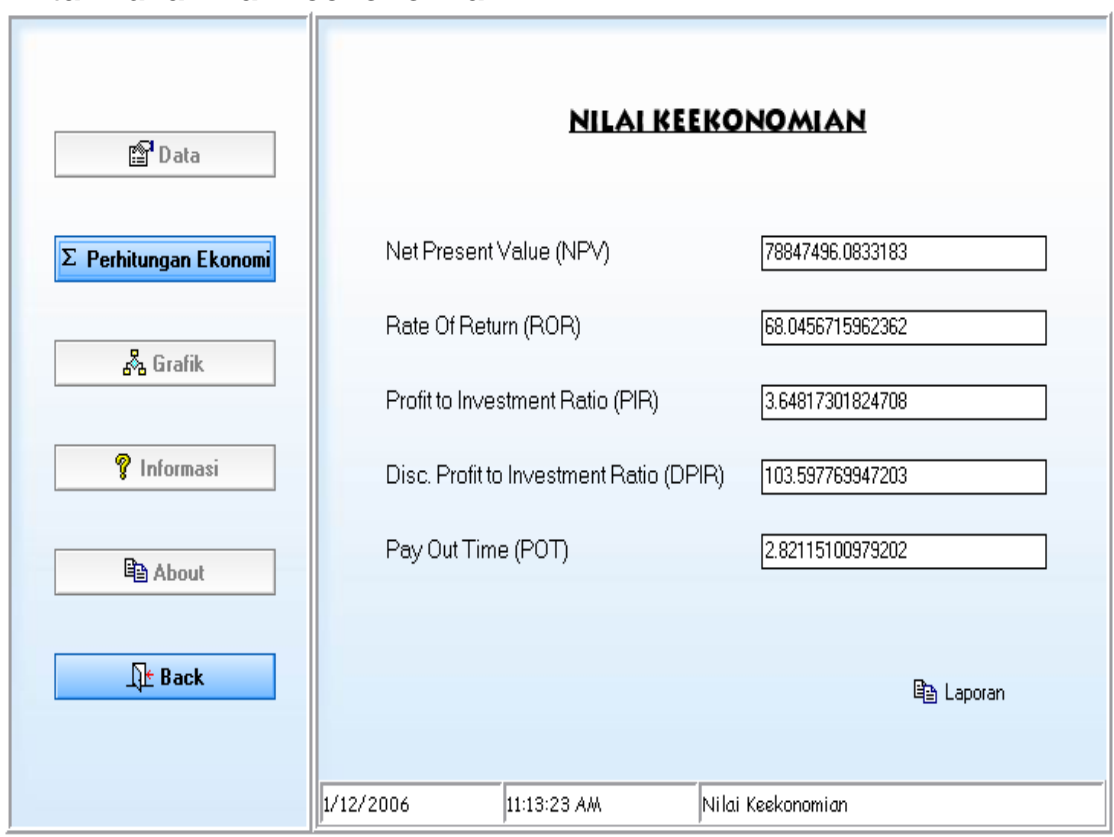

Gambar 3.9. Antarmuka Nilai Keekonomiaan 
e. Antarmuka Grafik

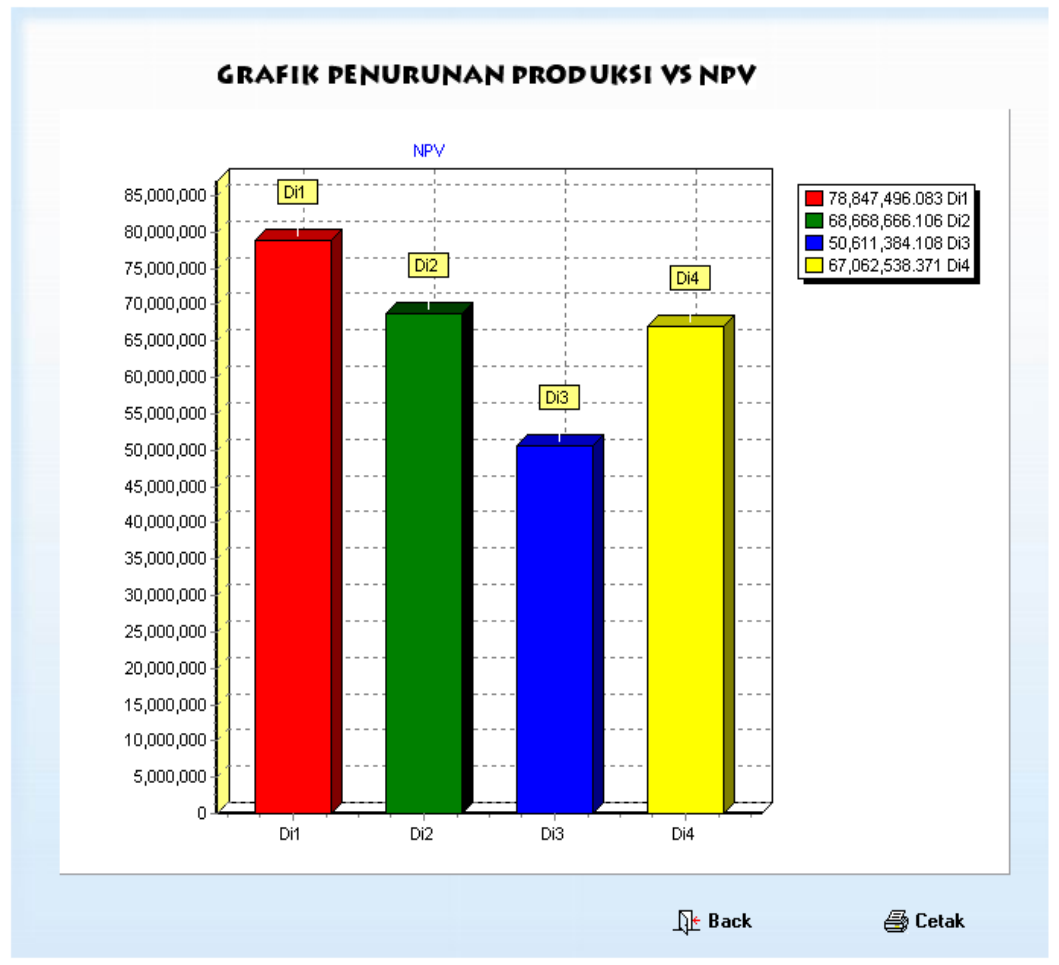

Gambar. 3.10. Antarmuka Grafik

\section{Kesimpulan}

Dari hasil perancangan sistem yang dilakukan, telah berhasil dibangun sebuah sistem pendukung keputusan untuk menentukan apakah suatu proyek pemboran sumur minyak layak untuk dikembangkan atau tidak yang didasarkan pada perhitungan ekonominya.

\section{Daftar Pustaka}

Daihani, Dadan Umar, 2001, Komputerisasi Pengambilan Keputusan, PT. Elex Media Komputindo, Jakarta.

Davis, Gordon B., 1999, Kerangka Dasar Sistem Informasi Manajemen, cetakan kesebelas, PT. Ikrar Mandiriabadi, Jakarta.

Fathansyah, 1999, Basis Data, InformatikaBandung, Bandung.

Jogianto, H.M, 1989, Analisis dan Desain Sistem Informasi, Andi, Yogyakarta.

Jogianto, H.M, 1995, Analisis dan Desain Sistem Informasi : Pendekatan Terstruktur Teori dan Praktek Bisnis, cetakan kelima, Andi, Yogyakarta.

Martina, Inge, 2003, 36 Jam Belajar Komputer : Microsoft SQL Server 2000, PT. Elex Media Komputindo, Jakarta.

Pranata, Antony, 1998, Pemrograman Borland Delphi, jilid 1, Andi, Yogyakarta.

Prayogo, Heri, 2005, Kajian Keekonomian Pengembangan Lapangan Marginal " $X$ ", Skripsi, Universitas Pembangunan Nasional "Veteran" Yogyakarta.

Pressman, Roger S., 2002, Rekayasa Perangkat Lunak, jilid 1, Andi, Yogyakarta.

Widjajono, Partowidagdo, Ir., Ph.D., 2002, Oil and Gas Project Management Course : Petroleum Economics, Jakarta. 